on cotton and staffed by the Colonial Agricultural Service.

Though no distinction should be drawn between fundamental and immediate research work, an orderly division should be made between general and local problems, the former being incorporated in the programme of the research station and the latter suggested for investigation at other stations. The research station should collaborate with the latter in the particular application of general results to local conditions, and its work should also be framed so as to be complementary to that of the Departments of Agriculture. The Corporation hopes to be able to provide the finance necessary for the recurrent expenditure of the research station, and the Colonial Office has been asked to approve in principle a grant being made after the War from the Colonial Research Fund to cover the capital cost of the station in land, buildings and equipment. The report of the Council also includes some notes on the work during the year of the Genetics Department and the Physiology Department of the Research Station, Trinidad, and on research work carried out at the Universities of Cambridge and Manchester, the Imperial College of Science and Technology, and the Rothamsted Experimental Station.

\section{Folk-lore Treatment of Sneezing}

THE March issue of the Bulletin of the History of Medicine contains an interesting article on contemporary folk-lore treatment of sneezing by Dr. Leo Kanner of Baltimore, who classifies the folk-lore remedies for this condition in the following categories : (1) suggestions, general or specific, of the healers whom the patient should consult ; (2) metaphysical cures and prayers, mental equilibrium and magnetic treatment ; (3) cure through fright ; (4) external remedies, such as pressing and rubbing; (5) local applications to the nasal mucous membrane; (6) spraying, inhaling, snuffling, smelling and gargling; (7) exhaling; (8) remedies per os; (9) complicated recipes; and (10) hygienic and dietetic measures. Dr. Kanner comes to the conclusion that contemporary folk-lore, despite its apparent simplicity, is a highly complex mixture of a number of different ingredients which consist of the retention of beliefs and practices dating back from the earliest times; borrowed but not fully understood gleanings from current scientific medicine; survival of methods which were part of the repertory of practitioners two or three generations ago; and references to present-day healing cults.

\section{Prophylaxis of Malaria in Argentina}

IN a recent paper (Bol. Of. San. Panamericana, 21, 233 ; 1942) Dr. Hugo J. D'Amato, secretary of the National Department of Hygiene at Buenos Aires, states that during 1940 , and especially from January until April, there was a decided increase in the number of cases of malaria in North Argentina, where the disease is endemic, with the exception of those areas protected by the public health services, thus proving the efficiency of the methods applied. More than 170,000 patients were examined by the services of the National Department of Health and more than 20,000 in the provincial and municipal institutions; this is an increase of 5 per cent on the figures of the previous year. $P$. falciparum accounted for 33 per cent of the infections as compared with 12 per cent for the previous year. In 1940, 11,200 more patients were treated than in 1939 and more dispensaries were opened. About 1,600 kgm. of quinine are distributed every year, health education is carried out intensively, nearly 350,000 pesos are set aside yearly for preventive work, and private donations add 50,000 . In $1940,30,250$ houses were visited, in 8,210 of which mosquitoes were found, chiefly Anopheles pseudopunctipennis and also a few $A$. arsimaculatus, $A$. agyritarsis, $A$. perizi and $A$. albitarsis. Drainage, filling in, and other sanitary procedures were carried out on a large scale. More than 200,000 litres of petroleum and 70,000 kilos of Paris green were used.

\section{Public Health in Chile}

ThE March issue of the Boletin de la Oficina Sanitaria Panamericana contains a survey by Dr. Pedro Aguirre Cerda, president of Chile, on the present state of public health in the Republic. Since the end of 1939 the country has been free from epidemic disease with the exception of one or two sporadic cases of typhus. Whereas, in 1938, 70 per cent of the conscripts serving in America contracted malaria, in 1940, there was not a single case. Special attention has been given to maternal and child welfare, and it is hoped that the present high infant mortality will be considerably reduced in two or three years. A scheme of medical attention is being planned to provide for mothers from the onset of pregnancy and for children from birth until they are able to work. The acute housing problem is being solved by providing hygienic and comfortable homes for workers at a low cost. Popular restaurants served approximately $2,000,000$ meals to $1,000,000$ persons in 1939 , and $4,000,000$ meals to $1,200,000$ in $1940 ; 5,000,000$ pesos have been allocated to aid deserted mothers and children as well as other handicapped persons.

\section{Earthquake in Spain}

An earthquake was felt in Granada in southern Spain early on July 12. According to human perception, the shock lasted for about ten seconds, although no damage or casualties have been reported. The epicentre was estimated to have been some eighteen miles from the city, and a slighter aftershock was felt a few minutes later. Since earthquakes show a marked tendency to recur in areas once affected, it is not surprising that earthquakes such as this one should occur. In southern Spain such shocks and smaller tremors are by no means infrequent, though probably one of the largest earthquakes to occur in Spain was that on November 1, 1755, near Lisbon, the written records of which were studied by the late Dr. C. Davison.

\section{Earthquakes in South America}

The United States Coast and Geodetic Survey, in co-operation with Science Service and the Jesuit Seismological Association, has determined the epicentres of two recent South American earthquakes. From seismographic reports from twenty-two observatories, the epicentre of the earthquake of May 14 at $2 \mathrm{~h}$. $13 \cdot 3 \mathrm{~m}$. U.T. provisionally turned out to be near lat. $1^{\circ} \mathrm{S}$., long. $79^{\circ} \mathrm{W}$. This is near the town of Riobamba, in Ecuador. From reports from five stations, the provisional epicentre of the earthquake of May 14 at 8 h. 39.0m. U.T. turned out to be on the bed of the Pacific Ocean, off Tumaco in Colombia. Both epicentres are in well known seismic regions. 